\title{
Sakk és matematika Játéktól a valóságig
}

\author{
Misetáné Burján Anita
}

Karádi Általános Iskola

\begin{abstract}
Napjainkban az érdeklődés középpontjába került a sakkoktatás. Egyre több helyen vezetik be a „királyi játék” oktatását Magyarországon. Húsz éve tanítok matematikát és sakkot egy általános iskolában. A pedagógusmunka egy igen összetett, komplex feladat. Egy életre szóló hivatás. A pedagógus számára igazi öröm, amikor többéves nevelö munkájával (osztályfönökként és szaktanárként) hozzájárul a gyerekek fejlődéséhez, átadja szakmai tudását, és ami talán a legfontosabb, hogy hozzásegíti tanítványait képességeik és készségeik kibontakoztatásában, személyiségük kialakulásában. A pedagógusok komplex munkájának egyik fokmérője, hogy tanítványaik hogyan teljesítenek vizsgaszituációkban. A cikkben néhány tapasztalatomat szeretném bemutatni, hogyan realizálódhat a korai sakkoktatás és versenyzés előnye a középiskolai központi matematikai felvételi vizsgán 1 .
\end{abstract}

Kulcsszavak: sakk, geometria, tájékozódás, játék, logika

Ez a feladatsor egy szakértők által összeállított országos mérés. A gyermek, a szülő, a tanár és az iskola közös célja, hogy a diákok ebben a kétszer 45 percben önmagukhoz mérten tudásuk legjavát nyújtsák. A most végzős nyolcadik osztályomban már első osztályos koruktól tanítottam sakkot (szakkör) és ötödik osztályos koruktól matematikát (tanóra és szakkör). Összehasonlítottam a sakkozó gyerekek és az összes tölünk felvételiző gyerek eredményét és jelentős különbséget találtam.

A 8. évfolyamosok országos eredményei 2014-ben² átlagosan matematikából 20,7 pont, magyarból 33,3 pont, az összesített 54,0 pont.

Iskolánkban, ebben az évben matematikából az átlag: 25,18 pont, magyarból 35,97 pont, összesen 61,15 pont.

Osztályomban az átlag matematikából 29,09 pont, magyarból 37,50 pont, összesen 66,59 pont.

A megyei „amatőr” sakk-diákolimpián részt vett tanulók átlaga matematikából 39,8 pont, magyarból 42,4 pont, összesen 82,2 pont.

Mivel ezekeket a gyerekeket matematikából (4 évig), sakkból (7-8 évig) és osztályfőnökként (4 évig) figyelemmel kísértem, a statisztikai adatok mellé a tapasztalataimat is összegyüjtöttem.

A gyerekek közül többen is tanultak sakkot alsó tagozatban, azonban az idei évben az új típusú „amatőr” sakkversenyen öten vettek részt. Az évfolyamban hatan lettek kitűnő tanulók (tanulmányi eredmény) félévkor, a sakkozók közül pedig ketten.

Csoportbontásban dolgozunk ezen az évfolyamon, csoportomban a 20 tanuló ugyanazt a felkészítést kapta. 30 komplett feladatsort oldottunk meg matematikából (szeptembertől januárig), mindegyiket 45 perc alatt, majd közösen kijavítottuk a hibá-

1 http://www.oktatas.hu/kozneveles/kozepfoku felveteli eljaras/kozponti feladatsorok

2 http://www.oktatas.hu/pub_bin/dload/kozoktatas/beiskolazas/felveteli_eredmenyek_2007 2014.pdf 
kat. A félévben háromszor (szeptember eleje, december vége, január eleje) mértük az egyéni eredményeket és összehasonlítottuk a fejlődést. Mindenki a saját egyéni fejlődését figyelhette és a végén már a saját hiányosságait tudta pótolni. Közben megtanultak a gyerekek gazdálkodni az idővel. Míg az elején nem tudták megoldani az összes feladatot, a végén már néhány percük maradt az ellenőrzésre is.

Tehát a pontokban való jelentős eltérést más okokban kell keresni. Úgy gondolom, hogy ezeknél a gyerekeknél a korai sakkoktatás és a versenyzés egyaránt hozzájárult a sikerhez.

Összegyűjtöttem azokat a tapasztalatokat, sakkbeli feladatokat, amelyeket már alsó tagozatban megismertek a gyerekek, és amelyek a felső tagozatos matematikai feladatoknál előnyt jelentettek számukra.

Először a geometriai feladatok „gyökereit” kerestem, amelyekkel ők már kisdiák korukban is találkozhattak a sakkjátékban.

Pierre M. van Hiele és Dina van Hiele-Geldof a geometriai gondolkodás fejlödésének öt szintjét különböztetik meg. Kutatásaikban megállapították, hogy ezek a szintek nem léphetők át, viszont a szintek elsajátításához szükséges idő eltérő lehet.

A geometriai ismeretek a sakkban is különböző szinteken jelennek meg. Alkalmazásuk a sakkparti folyamán nélkülözhetetlen. A téri tájékozódás, a térelemek a sakktáblán, a koordináta-rendszer, a síkbeli alakzatok, a geometriai transzformációk egyaránt előkerülnek a sakk tanítása során már alsó tagozatban vagy akár fiatalabb gyerekeknél is.

A sakk tanítását a legtöbben a sakkfigurák megismertetése után a sakktáblával és részeivel folytatják (Asztalos és Bán, 2001; Fekete, é.n.; Mészáros, 2007; Polgár, 2013).

A sakktábla segítségével sok geometriai fogalmat játékos formában ismernek meg a gyerekek. A síkidomok, sokszögek közül a négyzet fogalmával tapasztalatszerzés alapján: A sakktábla négyzet alakú. Mutasd meg a határoló vonalait! (kerület) $A$ sakktáblán 64 mező (terület $8 * 8$ ) található. Ezek is négyzet alakúak (hasonló síkidomok, a kisebb-nagyobb fogalma). Mutasd meg az e4, e5, d4, d5 mezőt! Ezek alkotják a centrumot. A centrum is egy négyzetet alkot a sakktáblán (kívül-belül, rész-egész). A négyzet fogalma a gyalogbevitel szabályainál (négyzetszabály) is előkerül. Ebben az esetben már a gyerekeknek absztrakt módon, a képzeletükben kell megalkotniuk a négyzete(ke)t.

- Téglalap: világos térfél, sötét térfél, királyszárny, vezérszárny

- Nyolcszög, trapéz: A huszár menetmódjának megtanítása során

Ezeket a gyerekeknek életkori, gondolkodási szintjüknek megfelelő időben, de mindenképpen az iskolai matematikai tananyagban való megjelenése előtt (Herendiné, 2005) már megtaníthatjuk.

Thurstone $(1951,1952)$ az intelligencia-kutatása során a faktoranalízis módszerét használva hét csoportfaktort ír le (verbális fluencia, verbális jelentés, számolás, perceptuális sebesség, tér, gondolkodás, memória). Ezek közül a térszemlélet az egyik legkomplexebb intelligenciafaktor, amely három részfaktorral jellemezhető (térbeli relációk, vizualizáció, térbeli tájékozódás). Linn és Petersen $(1985,1986)$ az ő kutatásait továbbfejlesztve 5 részfaktort különböztet meg (térbeli relációk, vizualizáció, térbeli tájékozódás, térbeli észlelés és mentális forgatás). A téri képesség a két- és háromdimenziós alakzatok észlelését és a velük való mentális müveleteket jelenti, amely a kognitív funkciók kapcsolatrendszerét feltételezi. Maier (1999) az objektumok térbeli viszonyainak megváltozása (statikus, dinamikus), illetve a megfigyelő helyzete (az objektumon belül, kívül) alapján hat részfaktort különböztet meg (térbeli relációk, térbeli 
észlelés, képzeletbeli mozgatás, vizualizáció, mentális forgatás, térbeli tájékozódás). Hegarty (2010) szerint a vizuális intelligencia „alkalmazkodó téri gondolkodás”, amelynek két komponensét különbözteti meg (meta-reprezentációs képességek, flexibilis stratégiai választás a gondolkodásnak a mentális szimuláció és az analitikus formája között).A statikus gondolkodási folyamatok közül a térbeli relációk észlelése és létesítése már az egyszerü matt állások felismerésekor és létrehozásakor előkerül. A képzeletbeli mozgatás a sakkfigurák alapállásba való elhelyezésekor játékosan fejleszthető.

A dinamikus gondolkodási folyamatok közül a vizualizáció a sakkjáték folyamán folyamatosan jelen van. A mentális forgatás a sakkparti minden egyes lépése után új szituációként fordul elő. A schnell-partik ezt a képességet még jobban fejlesztik. A térbeli tájékozódás fejlesztésére is sok lehetőség van a sakk segítségével.

A koordinátarendszer az 5 . osztályos matematikai tananyagban szerepel. A mezők jelölésének megtanítása is ezeket az ismereteket készíti elő. Az élő sakkjátszma folyamán a gyerekek egyik mezőről a másikra mennek. A sakkpartiban a sakkfigurákat mozgatják (cselekvéses tanulás). A mattfeladványokban, -kombinációkban több lépést előre kell kiszámolni, melynek során képzeletben kell megalkotni a lépések után kialakult állásokat. A vaksakk már egy sokkal magasabb szintet követel meg, amikor a játékos a tábla nélkül, a képzeletbeli térben eligazodik és tudja követni a tér dinamikus változását. Egy sakkjátszma során ezek a részfaktorok komplex módon fejlődnek.

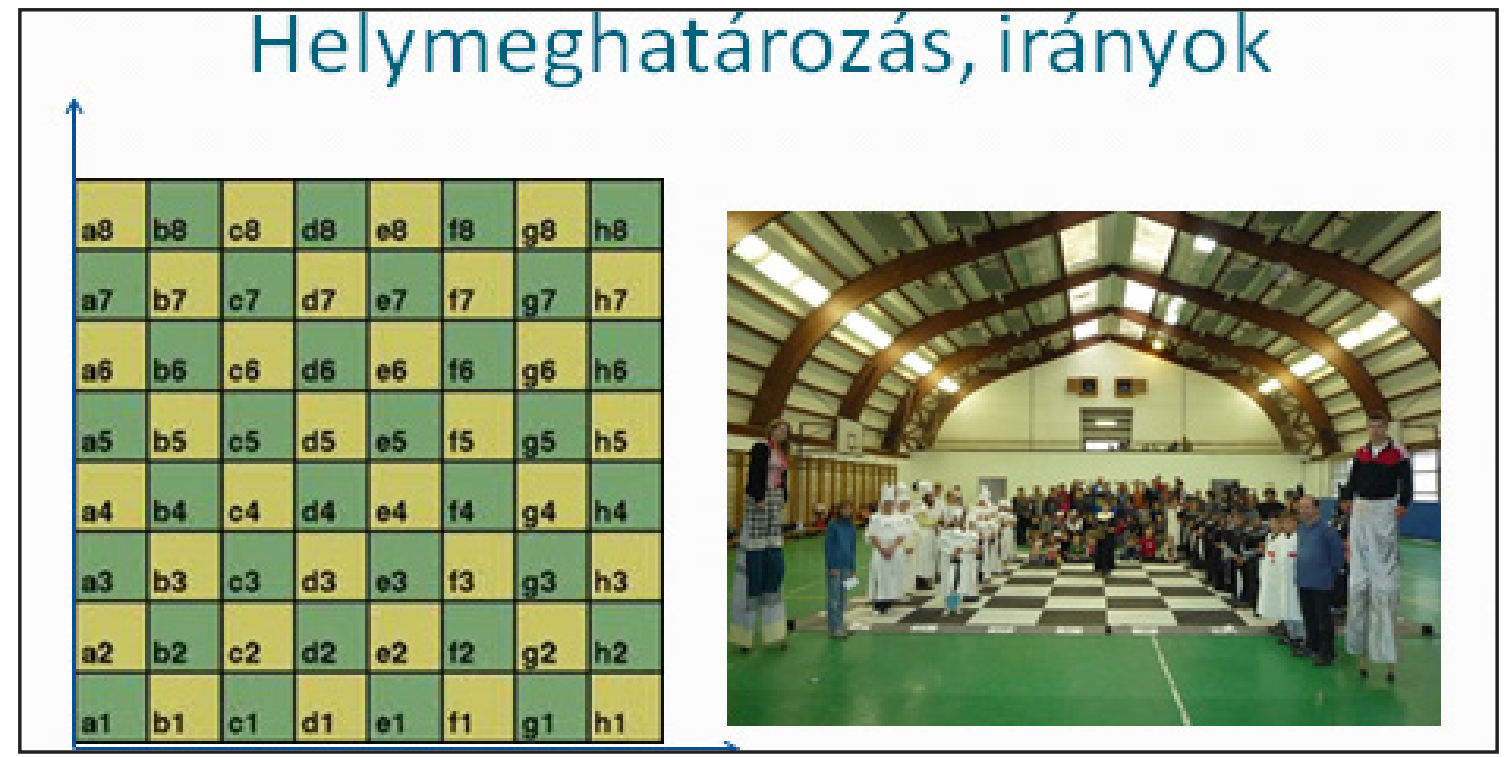

1. ábra: A sakktábla és a koordináta-rendszer kapcsolata (balra), Élősakk-bemutató, Balatonlelle 2009 (jobbra)

A sakkjátszma lejegyzése is a koordináták segítségével történik. Mivel már alsó tagozatos gyerekeknek is rendeznek olyan versenyeket, ahol a játszmák írása kötelező, ezért nekik már készség szinten tisztában kell lenniük mezők jelölésével, vagyis a koordinátákkal.

A 2014-es felvételi vizsga 7. feladatában a koordinátarendszerben megadott 3 pont segítségével paralelogrammát kellett előállítaniuk, ahol ez a 3 pont a paralelogramma 3 csúcsa és a 4. pontot nekik kellett megtalálniuk.

Ennek a feladatnak a megoldása során a legtöbb gondot tanítványaimnak a teljes megoldás megtalálása okozta. Sokan eljutottak az egyik paralelogrammáig, de a második és a harmadik paralelogrammát már nem keresték. A sakkozóknál előnyt 
jelentett, hogy a figurák lépéseinek vizsgálatakor nekik mindig több irányban kell gondolkodniuk (pl. a futó 4 irány, a vezér 8 irány, a huszár esetében ez az elhelyezkedéstől függően 2-8 irány).

A figurák lépéseinek megtanítása elősegíti a vektorok és az elmozdulás fogalmának tapasztalati úton, kicsiknél cselekvéssel (végig próbálják a lépéseket), nagyobbaknál gondolkodással (fejben végigszámolva, absztrakt módon) való megtanítását.

- A sakkfigurák lépései egy adott vektor melletti elmozdulásnak is tekinthetők.

- A huszárlépéseknél egyenlő nagyságú, de más irányú vektorok mutathatók meg (vektorok összege is elökerülhet).

- A bástyalépéseknél, futólépéseknél egyező irányú, ellentétes irányú, merőleges, egyenlő és különböző nagyságú vektorok mutathatók meg.

- A vezérlépések a legbonyolultabbak, itt az előzőeken kívül a vektorok által bezárt szög is megmutatható.

- A sakkjátékban két ismert fogalom a támadás és a védés.

- Hány figura támadja a huszárt? (Keresd meg az összes olyan vektort, ami az adott pontba mutat és az ellenfél bármelyik figurájából, mint pontból indul ki!)

- Hány figura védi a huszárt? (Keresd meg az összes olyan vektort, ami az adott pontba mutat és bármelyik saját figurából, mint pontból indul ki!)

- Ellentett vektorok (például amikor két gyalog, vagy két huszár kölcsönösen támadja egymást).

A geometriában a cselekvéses tanulás nem csak a sakk segítségével érhető el, de kiváló módszer a játék segítségével a kisgyerekek ismereteinek fejlesztésére.

Osztályomban a sakkozók a geometriai feladatokban 20, 19 és 33\%-kal jobban teljesítettek.

A legnagyobb eltérés a 10 . feladatnál fordult elő (55\%), amely egy arányossággal megoldható feladatnál bonyolultabb összefüggések felismerését igényelte. A térfogatszámítással megoldható feladatnál (9.) 33\%-kal jobb teljesítmény nyújtottak az átlaghoz képest, sőt egymástól különböző hibátlan megoldást is adtak (átdarabolás, kiegészítés, részekre bontás). A számolási készséget és pontosságot igénylő példánál (1.) $27 \%-k a l$, a kombinatorika segítségével megoldhatónál (3.) pedig 25\%-kal múlták felül társaik teljesítményét.

A matematikai gondolkodásmódra való képességek (absztrakciókészség, logikus következtetés, önbizalom, fantázia, emlékezőképesség, türelem, kitartás, önkontroll, önkritika) és a sakkozó pszichogramja 14 pontban hasonlóságot mutat. A sakk általános képesség- és készségfejlesztő hatása ismert és több kutatással alátámasztott felismerés. Ezt erősíti meg az is, hogy a sakkozó gyerekek nem csak a matematika, hanem a magyar felvételi vizsgán is jobban teljesítettek.

A jobb eredmény legfontosabb okai a gyerekek elmondása szerint, hogy ők nem ijedtek meg az új feladatoktól és az idővel is nagyon jól tudtak gazdálkodni. A sakkozó gyerekeknek életében az idő nagyon fontos szerepet játszik (egy játszmában meghatározott idő alatt meghatározott lépésszámot kell megtenni, például 2 óra alatt negyven lépést vagy 5-5 perc alatt egy teljes partit) Egyrészt a gondolkodási idejüket be kell tudniuk osztani a sakkparti folyamán. Másrészt minden lépésükkor döntést kell hozniuk. A lépésekkor felhasznált idő ezért nagyon eltérő lehet. Ezt már gyakran óvodás, illetve kisiskolás korban elsajátítják.

A középiskolai központi matematikaírásbeli-vizsgán 45 perc alatt kell 10 feladatot megoldani. Tehát átlagosan 4,5 perc jut egy feladat megoldására. Azonban a gyerekek nem ilyen egyenletesen oldják meg a feladatokat, hanem a számukra könnyebb feladatokat gyorsabban, a nehezebb feladatokat lassabban. Itt azonban lehetőség van egy feladat kihagyására is, illetve a feladatok megoldási sorrendjének megváltoztatására, amire a sakkban nincs lehetőség. 


\section{Összegzés}

A sakkjáték korai megtanítása, tanulása tehát jelentősen elősegíti a gyerekek geometriai ismereteinek fejlődését. Az idővel való gazdálkodásuk is fejlettebb társaiknál. $A$ pontosságuk fejlesztését szolgálja, hogy a sakkpartiban minden egyes megtett lépésnek következménye van (ez gyakran a játszma elvesztése vagy megnyerése is lehet). A sok megtehető lépés közül nekik kell kiválasztani az adott állásban a legjobb lépést, mégpedig úgy, hogy legtöbbször nincs lehetőségük (például idő hiányában) az összes lehetőség megvizsgálására.

A jelenlegi Z-generációnak éppen az egyik legnagyobb problémája, hogy a rá zúduló óriási információmennyiségből hogyan tud válogatni, hogyan tudja alkalmazni a megszerzett ismereteket. A gondolkodás, a kreativitás és a pontosság fejlesztésében pedig a matematika és a sakk is óriási szerepet játszik.

\section{Irodalom}

Asztalos Lajos - Bán Jenő (2001): A sakkjáték elemei. Kossuth Kiadó, Budapest.

Fekete József (é.n.): Sakk munkatankönyv I-IV. Kiadja a Magyar Sakkszövetség Ifjúsági Bizottsága, Budapest.

Hegarty M. (2010): Components of spatial intelligence. Psychology of Learning and Motivation Herendiné Kónya Eszter (2007): Kisiskolások térbeli tájékozódó képességének fejlesztési lehetőségei. PhD-értekezés Debreceni Egyetem Természettudományi Doktori Tanács Matematikai és Számítástudományok Doktori Iskola, Debrecen.

Linn, M. C., Peterson, A. C. (1985): Emergence and characterization of sex differences in spatial ability: A meta-analysis. Child Development, 56 (6), 1479-1498.

Maier, P, H (1999): Raumliches Vorstellungsvermögen. Auer Verlag, Donauwörth.

Mészáros András (2007): Sakk-matt I. G. L. Újvilág BT, Eger.

Polgár Judit (2013): Sakkjátszótér, Magánkiadás.

Thurstone, L., L. (1951): Primary Mental Abilities. In: American Association for the Advancement of Science, Centennial.

Thurstone, L., L. (1950): Some Primary Abilities in Visual Thinking. Proceedings of the American Philosophical Society

Tosev, Jurij (1974): A sakkozó pszichogrammja, Magyar Sakkélet, 13. 1. szám, 12. o)

http://www.oktatas.hu/kozneveles/kozepfoku felveteli eljaras/kozponti feladatsorok

http://www.oktatas.hu/pub_bin/dload/kozoktatas/beiskolazas/felveteli_eredmenyek_2007_2014.pdf 


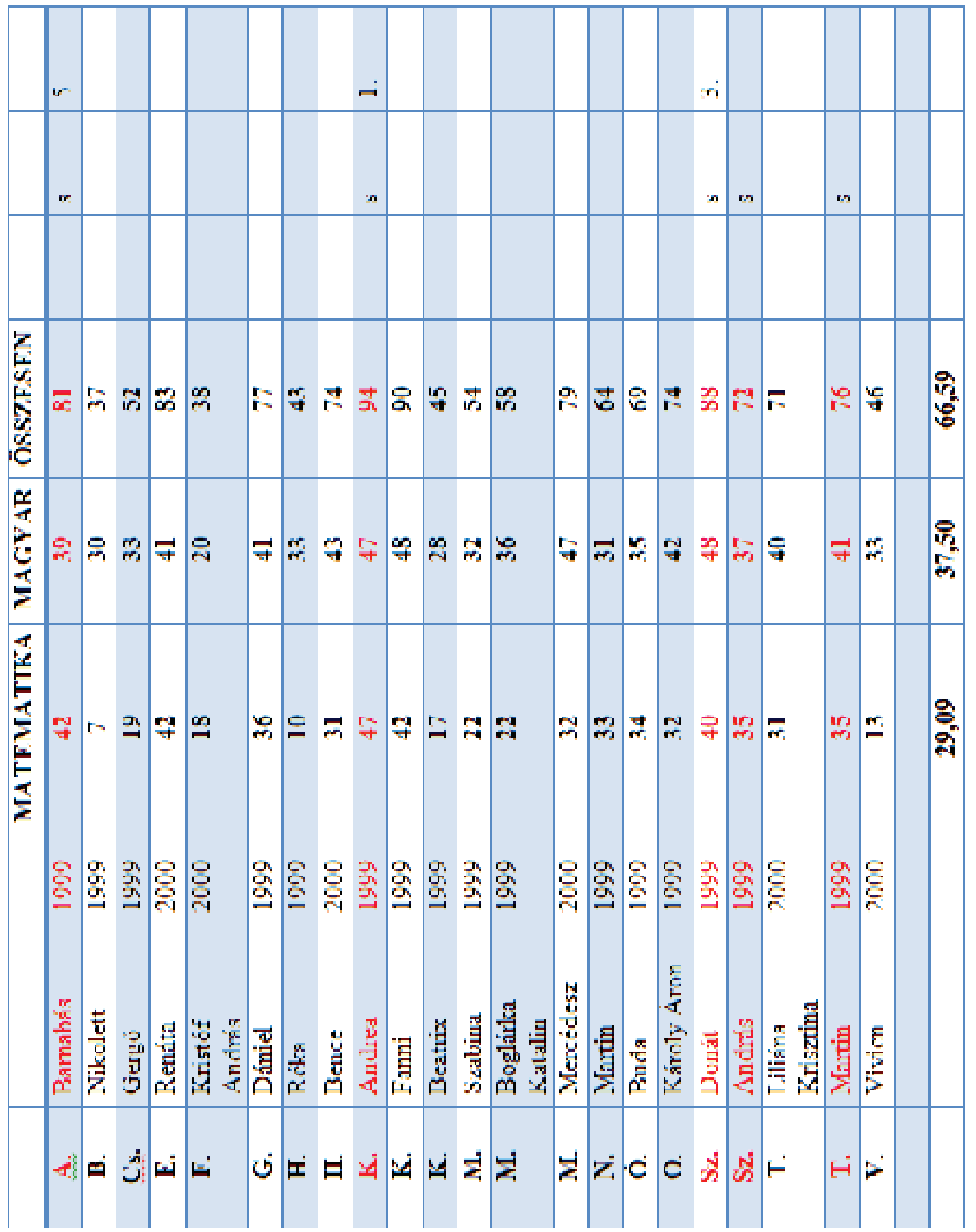

A 8.b osztály eredménye matematikából feladatonként (2014. évi központi írásbeli felvételi vizsga) 


\begin{tabular}{|c|c|c|c|c|c|c|c|c|c|c|c|c|c|c|c|c|c|c|c|c|c|c|c|}
\hline & $\therefore i$ & & & $\rightarrow$ & & $\nabla$ & & & - & $-i$ & & & & & & & & लri & $\sim{ }^{\circ}$ & & شे & & \\
\hline & $\alpha$ & & & & & & & & v. & & & & & & & & & w & n & & wa & & \\
\hline 室 & $\tilde{y}$ & $r-$ & 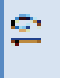 & 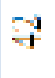 & $\stackrel{c o s}{\square}$ & in & 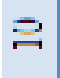 & rir & 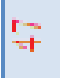 & 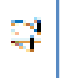 & $\approx$ & 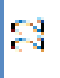 & $\approx$ & $r$ & $m$ & 吉 & 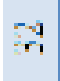 & 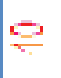 & 9 & $\Rightarrow$ & $m$ & $\because$ & 马i \\
\hline 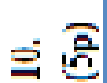 & $t$ & $\infty$ & - & -4 & $\infty$ & $=$ & $\rightarrow$ & $r a$ & $r i$ & $\infty$ & 0 & $r u$ & 0 & 7 & $\infty$ & $\sim$ & $r_{1}$ & $r .4$ & $\mathrm{Cr}$ & $\neg$ & $\leftrightarrow 4$ & 0 & 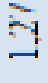 \\
\hline$\frac{\vec{a}}{a}$ & -1 & 0 & 0 & + & 0 & $\sigma$ & 0 & $\longrightarrow$ & ar & + & $\Longrightarrow$ & 0 & 0 & $\rightarrow$ & 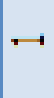 & 0 & 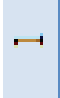 & 0 & $n$ & 0 & en & 0 & 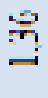 \\
\hline$\underset{\infty}{\frac{2}{6}}$ & 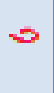 & 0 & 0 & 0 & 0 & $c$ & 0 & $\leadsto$ & $\infty$ & 0 & 0 & 0 & $\rightarrow$ & 0 & $\leadsto$ & $n$ & 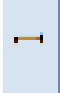 & 6 & C-1 & 0 & 0 & 0 & $\approx i$ \\
\hline$\underset{r}{3}$ & -3 & 0 & 0 & $=1$ & $\leadsto$ & $r$ & -1 & es & $\infty$ & + & 0 & 0 & Cr & -1 & $\leftarrow$ & 0 & 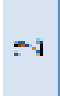 & $\tau$ & Cr & 0 & es & 0 & $\stackrel{5}{3}$ \\
\hline 룰 & 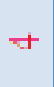 & es & $r$ & + & $\tau$ & 寸 & $\rightarrow$ & en & 寸 & + & en & $\tau$ & Cr & + & en & $\mathrm{m}$ & + & $\tau$ & $\mathrm{m}$ & $\pi$ & $\tau$ & $\mathrm{Cr}$ & 空 \\
\hline$\frac{\sqrt{2}}{3}$ & $\leadsto$ & 0 & 0 & $\leadsto$ & 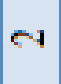 & 寸 & 0 & n & r & 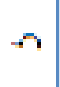 & $\rightarrow$ & 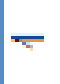 & $m$ & $m$ & n & $n$ & व & $n$ & $\mathrm{~N}$ & $\rightarrow$ & 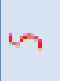 & 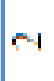 & $\underset{7}{7}$ \\
\hline$\stackrel{3}{3}$ & 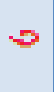 & N & $c$ & 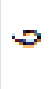 & $\infty$ & 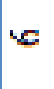 & $\rightarrow$ & $T$ & 40 & 0 & m & $\digamma$ & 寸 & 0 & 0 & 0 & 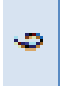 & $\infty$ & $\infty$ & 寸 & 6 & $\infty$ & i \\
\hline$\frac{12}{2}$ & $\leadsto$ & $\longrightarrow$ & 寸 & $\rightarrow$ & $\longrightarrow$ & r & $\rightarrow$ & 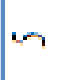 & 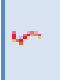 & $\rightarrow$ & $m$ & m & $m$ & $\rightarrow$ & $m$ & $n$ & $m$ & $\curvearrowleft$ & $n$ & $\rightarrow$ & $\backsim$ & $\rightarrow$ & $\because$ \\
\hline$\frac{\bar{z}}{\mathrm{e}}$ & $\nabla$ & 0 & 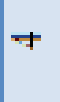 & 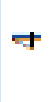 & 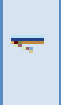 & or & $\longrightarrow$ & $\mp$ & + & $\leadsto$ & - & N & $\mp$ & व & $m$ & $\mp$ & व & 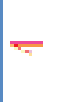 & 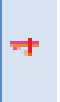 & $m$ & $\mp$ & $r$ & $\stackrel{+}{g}$ \\
\hline \multirow{3}{*}{ 胥 } & $\nabla$ & r & $n$ & $\nabla$ & $\infty$ & $\nabla$ & 0 & $\infty$ & $T$ & $\nabla$ & $m$ & $m$ & $m$ & $\nabla$ & $m$ & $\nabla$ & $\Rightarrow$ & $\mp$ & $\nabla$ & व & $\nabla$ & 0 & 3 \\
\hline & 承 & 鴌 & 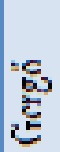 & 获 & 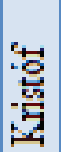 & 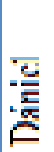 & 苟 & 岁 & 突 & 录 & 莺 & 喜 & 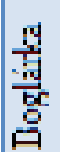 & 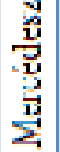 & 莺 & 尊 & $\begin{array}{l}3 \\
3 \\
3\end{array}$ & 壹 & 急 & 当 & 总 & 壳 & \\
\hline & $x^{4}$ & قم & ச் & ند & " & تن & 포 & 田 & 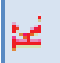 & 4 & ت & $\geq$ & 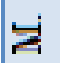 & $z$ & $\not$ & 0 & 5 & N & 头 & $=$ & $\rightleftarrows$ & $p$ & \\
\hline
\end{tabular}




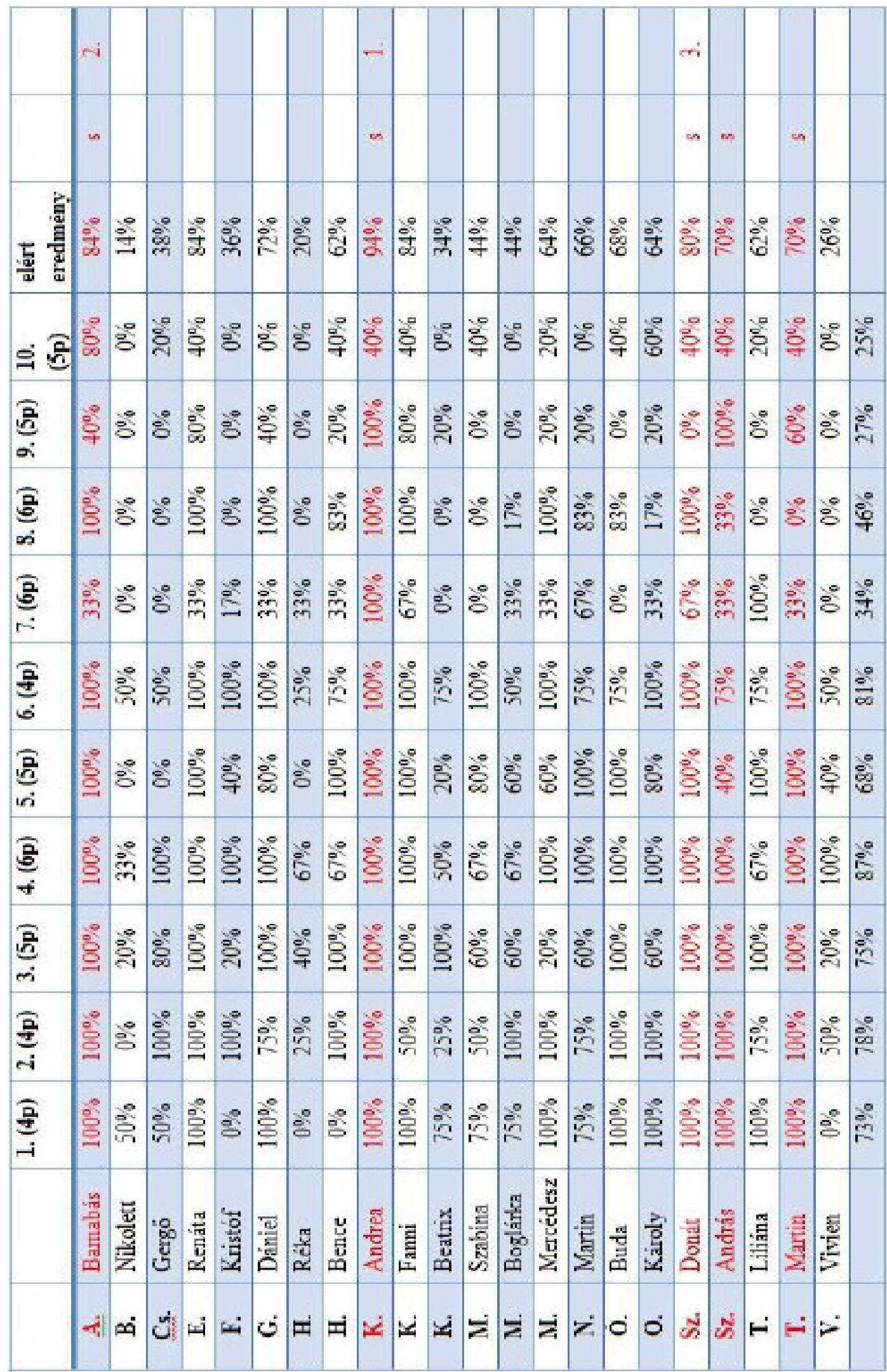

A 8.b osztály eredménye matematikából feladatonként (2014. évi központi írásbeli felvételi vizsga) 